\title{
Impact of GST on MSMEs
}

\author{
Shetty Deepa Thangam Geeta, SP. Mathiraj, M.Thivya Bharathi
}

\begin{abstract}
MSME play a vital in the economical progress of the Countries, so the implementation of GST has had an immense outcome on the continued existence in the market. Some enterprises found it helpful however majority visage problem in adopting it. For existing enterprises, GST simplified the tax structure, unified the market thus improved among all operational efficiencies of MSME, to this point the unorganized MSMEs were growing quick than the organized ones as a result of the minimization, with GST in effect, it has made the taxation system transparent thus making the entities liable for tax payment. This paper brought out issues and challenges experienced by MSME Entrepreneur. In order to find out the impact on various aspect such as applying of GST, created the registration for taxation and High Compliance burden by using Cluster Random Sampling Technique in which $158 \mathrm{MSME}$ Entrepreneur were selected in Sivaganga District in Tamil Nadu for the study. The statistical tools used for the analysis is one-way ANOVA. ANOVA is used to identify the significance of the difference in the levels of impact of GST among MSMEs. It was concluded that the impact of GST on the Indian MSME sector can go both positive and negative ways.
\end{abstract}

\section{Keywords: GST, Issued faced, Levels of Impact, MSME.}

JEL Classification: L26, G18, H20, Z13

\section{INTRODUCTION}

$\mathrm{T}_{\mathrm{ax}}$ is a method of collection revenue from people, corporations or different entities by the govt. so as to finance state expenditure. It is considered as the most important source of government's income to drive economic growth and achieve the status of a developed country and high income. Goods and service Tax (GST) combines each the present Central and State Taxes within the country into a solitary tax, thereby eliminating the twin taxation system and facultative a joint nationwide market. The implementation of this tax permits the govt. to possess an improved hold on the taxpayers, which, in turn, improves the entire tax pattern and has many alternative advantages. This MSME sector of the market has been deliberated because of the chief development driver of the Indian economy for years. MSMEs have emerged because of the principal employment-creating section in India and have

Revised Manuscript Received on July 22, 2019.

Shetty Deepa Thangam Geeta, Commerce, Alagappa University, Karaikudi, India. Email: dramrajsuji@gmail.com

Dr. SP. Mathiraj, Corporate Secretaryship Alagappa University, Karaikudi, India.. Email: drmathiraj@gmail.com

M.Thivya Bharathi, Corporate Secretaryship Alagappa University, Karaikudi, India.. Email: assthivya@gmail.com delivered stable growth through numerous sectors of our developing nation. The impact of GST on MSME has brought vast change. This study will be useful for MSMEs entrepreneurs to overcome the negative impact through GST implementation.

\section{REVIEW}

Shalini Shukla \& Ram Singh (2018) ${ }^{1}$ there is mixed anticipation and different responses on GST from manufacturers, service providers, and different market intermediaries. There is lack of such studies, specifically in the context of India, that provide any empirical support on either positive or negative impact of GST. Thus, the present study sought to empirically analyze the performance of companies after one year of GST implementation. Probability sampling was used to get the relevant sample. A total of 192 BSE listed companies were taken for analysis. Financial parameters (total assets, profit, and market capitalization for FY2017 and FY 2018) and demographic variables (size and experience of companies) were used to analyze the impact of GST roll out. The results indicated that among all three financial parameters, only total assets were significantly different from the pre GST time (FY2017). Further analysis highlighted that age and size of the company also affected the equation and was found significant in influencing the performance of companies after GST implementation. Detailed analysis and results were subsequently discussed in this paper. The study brought forth new insights on effect of new indirect tax regime on financial performance of the companies in order to fill the research gap. The results of the study will be useful for policy makers, strategists, and managers to cope up with the challenges posed by GST.

M. Jayalakshmi \& G.Venkateswarlu (2018) ${ }^{\mathbf{2}}$ Goods and Services Tax (GST) is an indirect tax which was introduced in India on 1 July 2017 and was applicable throughout India which replaced multiple cascading taxes levied by the central and state governments. It ${ }^{\mathrm{ee}} \mathrm{s}$ true that GST means „Great Step towards Transformation "e, „Great Step towards Transparency ${ }^{\text {ee }}$ in India and it is also true that someone gives „,birth ${ }^{\text {ee }}$ while someone else ,nurtures it ${ }^{\text {ee }}$. It has been long pending problem to streamline all the specific types of oblique taxes and put into effect a "single taxation" system.

\footnotetext{
${ }^{1}$ Singh, S. S. (2018, November). GST in India : Performance of Companies After One - Year of Roll Out. INdian Journal of Finance, 12(11).doi:http://dx.doi.org/10.17010/ijf\%2F2018\%2Fv12i11\%2F138197

${ }^{2}$ G.Venkateswarlu, M. J. (2018). Impact of GST on Micro, Small and Medium Enterprises (MSMEs). International JouryghofEEggineering and Management Research, 8(2), 91-95. 
Because the name indicates, the GST could be levied each on items and offerings. GST is a tax that needs to pay on supply of products \& offerings. Any person, who is presenting or offering goods and services, is liable to fee GST. Now we are witnessing, how this tax reform reshapes our economy and business dynamics for Micro, Small and Medium Enterprises. Flourishing amidst a challenging environment, the Small and Medium Enterprises (SMEs) of India experienced several highs and lows in the past few years. With the Indian economy expected to emerge as one of the leading economies in the world and likely to become a $\$ 5$ trillion economy by 2025 , major impetus is being given to strengthen the back bone of our economy-the SME sector. This paper highlights to know the GST and MSMEs and Impact of GST and MSMEs.

\section{NEED FOR THE STUDY}

Small scale industrial sector is an important segment of Indian economy. It generates employment opportunity next to agriculture sector. India is divided into 36 states including union territories among which some of the states such as Uttra Pradesh, West Bengal, Gujarat and Tamil Nadu are industrially advanced and retaining the dominant position in India. At present, the state of Tamil Nadu was divided into 32 districts. Chennai, Coimbatore, Tiruchirappalli, Kanchipuram, Salem, Thriuvallur, Vellore and Tuticorin are the main districts of industrial and commercial activities. From which Sivagangai is an industrially and economically backward district in Tamil Nadu. Some of the SSIs in Sivagangai district are flourished a lot and some of the mare not showing good performance. So, the researcher is interested to take up the research work on growth, trends problems and prospects of Micro and Small Enterprises in Sivagangai district of Tamil Nadu.

\section{SALIENT FEATURE OF STUDY AREA}

Sivaganga District comprises of nine taluks namely, Sivaganga, Manamadurai, Ilayangudi, Devakottai, Karaikudi, Thiruppathur, Thirupuvanam,Kalaiyarkovil and Singampunari (08.05.2017) This district is bounded on the north by Tiruchi and Pudukottai districts, on the east and south by Ramanathapuram district and on the west by Virudhunagar district. In September 1997 the Government of Tamil Nadu changed the name of the district as Sivaganga District. ${ }^{3}$

\section{Name of the Important Industry in the District:}

1. Sakthi Sugar Mills (P) Ltd., Padamathur, Sivaganga Dist.

2. Tamilnadu Minerals Limited (TAMIN), Karaikudi

3. Sri Vadivambigai Textiles Sakkanthi, Sivaganga District.

4. Tamilnadu Chemical products, Kovilur, Karaikudi Tk.

5. Tamilnadu Clorides Ltd., Pottapalayam,Tiruppuvanam Tk.

Table- I: Micro, Small and Medium Enterprises in Sivagangai District

Statistical Hand Book of Sivagangai ,2017 https://cdn.s3waas.gov.in/s31a5b1e4daae265b790965a275b53ae50/uplo ads/2018/06/2018062188.pdf

\begin{tabular}{|c|c|c|}
\hline S.No & MSME Activity \& Classification & $\begin{array}{c}\text { No. of units } \\
\text { As on } \\
\text { 31.03.2017 } \\
\end{array}$ \\
\hline 1 & $\begin{array}{l}\text { Agriculture, Hunting and Related } \\
\text { Service Activities }\end{array}$ & 56 \\
\hline 2 & Other Mining and Quarrying & 5 \\
\hline 3 & $\begin{array}{l}\text { MFG of Food Products and } \\
\text { Beverages }\end{array}$ & 138 \\
\hline 4 & MFG of Textiles & 50 \\
\hline 5 & $\begin{array}{l}\text { MFG of Wearing Apparel Dressing } \\
\text { and Dyeing of fur }\end{array}$ & 13 \\
\hline 6 & $\begin{array}{l}\text { MFG of Leather \& Leather } \\
\text { products }\end{array}$ & 9 \\
\hline \multirow[t]{2}{*}{7} & MFG of Wood \& Wood products & 53 \\
\hline & MFG of Paper \& Paper products & 14 \\
\hline 9 & $\begin{array}{l}\text { Publishing, Printing \& } \\
\text { Reproduction of Recorded Media }\end{array}$ & 17 \\
\hline 10 & $\begin{array}{l}\text { MFG of Chemical \& Chemical } \\
\text { products }\end{array}$ & 10 \\
\hline 11 & $\begin{array}{l}\text { MFG of Rubber and plastic } \\
\text { products }\end{array}$ & 3 \\
\hline 12 & $\begin{array}{l}\text { MFG of other Non- Metallic } \\
\text { mineral products }\end{array}$ & 22 \\
\hline 13 & MFG of Basic Metals & 61 \\
\hline 14 & MFG of Fabricated Metal Products & 24 \\
\hline 15 & $\begin{array}{l}\text { MFG of Machinery and } \\
\text { Equipments }\end{array}$ & 5 \\
\hline 16 & $\begin{array}{l}\text { MFG of electrical Machinery and } \\
\text { apparatus NEC }\end{array}$ & 5 \\
\hline 17 & $\begin{array}{l}\text { MFG of radio, Television and } \\
\text { Communication equipment and } \\
\text { Apparatus }\end{array}$ & 116 \\
\hline 18 & $\begin{array}{l}\text { MFG of Motor Vehicles, Trailers } \\
\text { and Semi-Trailers }\end{array}$ & 1 \\
\hline 19 & $\begin{array}{l}\text { MFG of other Transport } \\
\text { Equipments }\end{array}$ & 0 \\
\hline 20 & $\begin{array}{l}\text { MFG of Furniture Manufacturing } \\
\text { NEC }\end{array}$ & 14 \\
\hline 21 & $\begin{array}{l}\text { Professional scientific and technical } \\
\text { activities }\end{array}$ & 71 \\
\hline 22 & Construction & 37 \\
\hline 23 & $\begin{array}{l}\text { Repair \& Maintenance of Motor } \\
\text { Vehicles, Retail Sale of Automotive } \\
\text { fuel }\end{array}$ & 284 \\
\hline 24 & Information and communication & 116 \\
\hline 25 & Financial and insurance activities & 35 \\
\hline 26 & Hotel and Restaurants & 71 \\
\hline 27 & $\begin{array}{l}\text { Administrative and support } \\
\text { activities }\end{array}$ & 113 \\
\hline 28 & $\begin{array}{l}\text { Human health activities and social } \\
\text { work activities }\end{array}$ & 32 \\
\hline 29 & Transport and storage & 37 \\
\hline 30 & $\begin{array}{l}\text { Manufacture of other non metallic } \\
\text { mineral products }\end{array}$ & 61 \\
\hline 31 & other manufacturing & 62 \\
\hline 32 & Real Estate Activities & 2 \\
\hline 33 & $\begin{array}{l}\text { Water supply sewerage waste } \\
\text { management }\end{array}$ & 17 \\
\hline
\end{tabular}




\begin{tabular}{|c|l|c|}
\hline 34 & $\begin{array}{l}\text { Electricity Gas steam and air } \\
\text { condition supply }\end{array}$ & 1 \\
\hline 35 & Other Business Activities & 27 \\
\hline 36 & Education & 9 \\
\hline 37 & Health and Social work & 32 \\
\hline 38 & $\begin{array}{l}\text { Recreational, Cultural and sport } \\
\text { Activities }\end{array}$ & 2 \\
\hline 39 & Other Service activities & 95 \\
\hline 40 & RCC Spun Pipes & $\mathbf{1 7 2 2}$ \\
\hline \multicolumn{2}{|c|}{ TOTAL } & \\
\hline
\end{tabular}

Source: G.M, DIC, Sivagangai ${ }^{4}$

\section{RESEARCH GAP}

As GST implemented in the recent year it had great impact on all the sectors in India. To brought forth new insights on effect of new indirect tax regime on MSMEs in Sivaganga District in order to fill the research gap. Hence the present study has been undertaken to bridge this gap and ascertain the views of Entrepreneur of MSMEs regarding GST.

\section{OBJECTIVES OF THE STUDY}

To analyze the impact of Goods and Services Tax (GST) on Micro, Small and Medium Entrepreneurs (MSMEs) in Sivagangai District, Tamil Nadu.

In pursuance of the above objectives, the following hypotheses were formulated for testing:

Ho ${ }^{1}$ There is no significant difference between the socio economic factors and impact on GST.

\section{RESEARCH METHODOLOGY}

\section{Sources of Data}

This study consists by both primary and secondary data. The primary data will be collected through the structured interview schedule selected Micro \& Small Scale industry on GST in Sivagangai district. The Secondary data have been collected from published and unpublished reports, handbooks, action plan, pamphlets of Director of Industries and Commerce, Chennai, District Industries Centre, Sivangagai and Panchayat Block Offices concerned. In addition, Text Books, Journals, Magazines, News papers, Government Gazettes, Reports of the Government and internet etc., have also been used.

\section{Sample Size and Sampling Technique}

There are $\mathbf{1 7 2 2}$ MSMEs in Sivagangai (as mentioned in Table I) out which $\mathbf{1 3 7 5}$ are registered as per the Annual Report UAM for the year 2017-18, there are 549 MSMEs in Enterprises, thus totaling 1375 MSMEs in Sivaganga District. In order to give due representation to all the categories of Manufacturing Enterprises 826 MSMEs in Service MSMEs, it is proposed to use "Cluster Random Sampling Technique" and 10\% of the population for Micro

${ }^{4}$ https://cdn.s3waas.gov.in/s31a5b1e4daae265b790965a27 5b53ae50/uploads/2018/06/2018062188.pdf category and $20 \%$ in case of Small category and $100 \%$ in case of Medium in view of the lower number of units in the population.

Questionnaire: The questionnaire was framed for the study. The questionnaire pertains to MSMEs view points on implementation of GST. The questionnaires were used to elicit information on items measuring demographic factors and level of impact on MSMEs with the aspects of GST.

Statistical Techniques: The statistical techniques used for analyzing the data vary from descriptive to multivariate. The details of the statistical tools are Frequency distribution analysis, Descriptive statistics like mean, standard deviation, Reliability analysis, Independent $t$-test, , One way ANOVA (also Called as F test), Correlation and Regression.

\section{DATA ANALYSIS}

\section{DESCRIPTIVE ANALYSIS}

Social Economic profile is both quantitative and quantitative aspects of selected human population .The following section presents the social and economic profile of the respondents which includes composition, gender, Age, Educational Qualification, Marital status and Monthly wise income.

\section{TABLE -II: DESCRIPTIVE ANALYSIS}

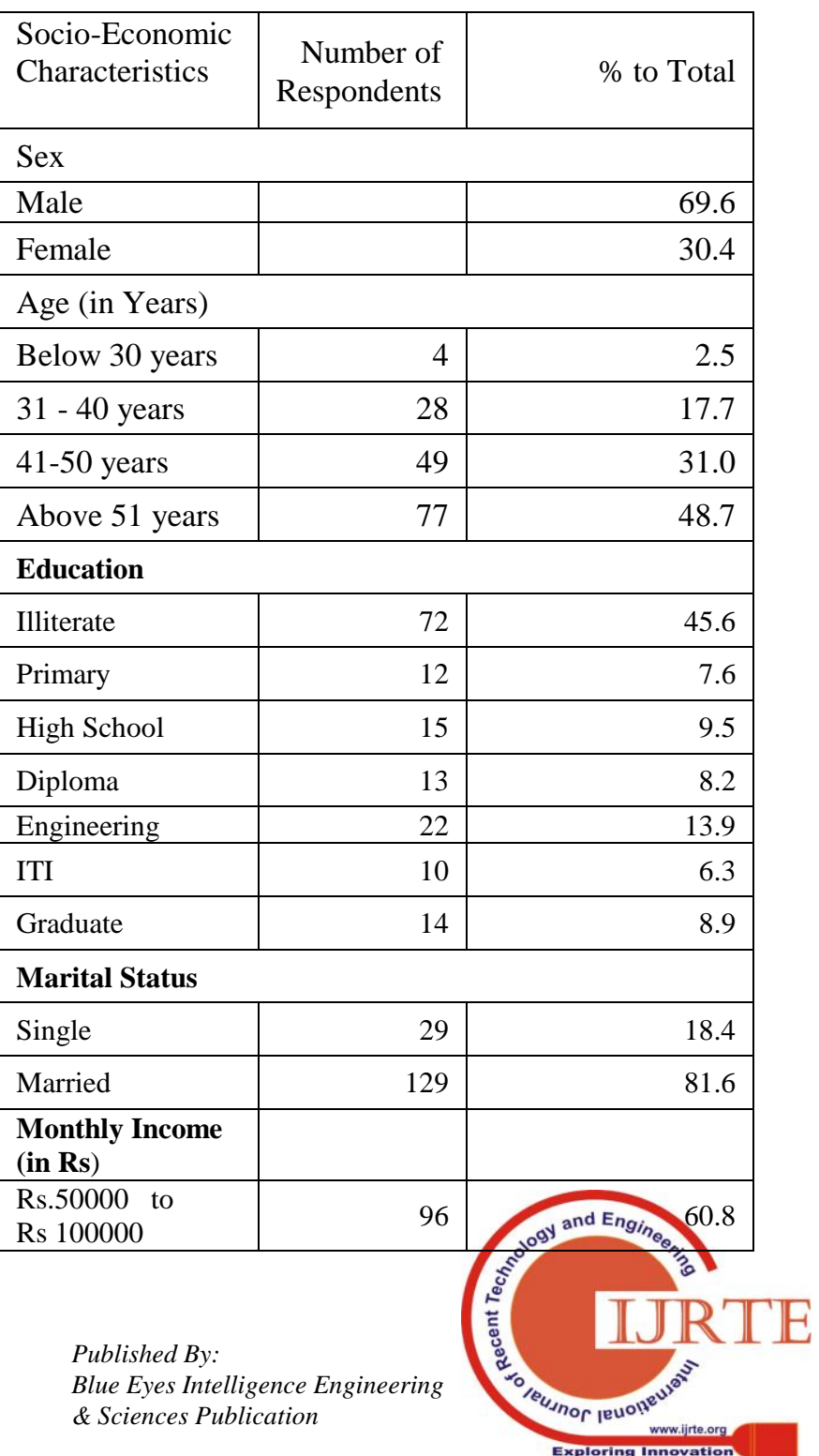




\begin{tabular}{|l|r|r|}
\hline $\begin{array}{l}\text { Rs } 100001 \text { to } \\
\text { Rs 200000 }\end{array}$ & 37 & 23.4 \\
\hline $\begin{array}{l}\text { Rs 200001 to Rs } \\
\text { 500000 }\end{array}$ & 19 & 12.0 \\
\hline Above Rs 500001 & 6 & 3.8 \\
\hline Total Sample & $\mathbf{1 5 8}$ & \multicolumn{2}{|c|}{$\mathbf{1 0 0 . 0}$} \\
\hline
\end{tabular}

Sources: Computed Data

It is observed from that the majority of the respondents are in the age group of above 51 years $(48.7 \%)$, followed by the respondent group with age level of 41-50 years $(31.0 \%)$ and $31-40$ years $(17.7 \%)$. The respondents who are Illiterate constitute $45.6 \%$ of the total sample followed by Engineering with $13.9 \%$.The monthly income level from Rs. 50000 to Rs 100000 is $60.8 \%$ followed by Rs 100001 to Rs 200000 is $23.4 \%$ of the respondents in the sample.

\section{RELIABILITY ANALYSIS OF IMPACT OF GST ON ENTREPRENEURS OF MSMES}

Table -III: Reliability Analysis

\begin{tabular}{|l|c|}
\hline \multicolumn{1}{|c|}{ Statement } & $\begin{array}{c}\text { Cronbach's } \\
\text { Alpha }\end{array}$ \\
\hline 1. GST impacted your business operation & 0.743 \\
\hline 2. Sales performance & 0.689 \\
\hline 3. Service Sector get costlier & 0.694 \\
\hline 4. Filing of taxes & 0.694 \\
\hline 5. Logistical overheads & 0.733 \\
\hline 6. Purchase of capital goods & 0.715 \\
\hline 7. Online Compliance Procedures & 0.690 \\
\hline 8.Elimination of multiple taxes & 0.742 \\
\hline Cronbach's Alpha & $\mathbf{0 . 7 2 8}$ \\
\hline
\end{tabular}

Sources: Computed Data

It can be inferred that out of 19 items in the scale for measuring level of impact of GST on MSMEs is acceptable for all the tenth scale items that is above 0.689 Cronbach's alpha coefficient value of 0.728 indicating an excellent reliability among the nineteen scale items. As the values of Cronbach's alpha were satisfactory, the study preceded its data analysis for further study.

\section{RELATIONSHIP BETWEEN AGE AND IMPACT OF IMPLEMENTATION OF GST}

This section the researcher attempts to test whether the age of the respondents affects the impact of GST. For this purpose the researcher has framed the hypothesis and tested it with the help of ANOVA test and the results are presented in the below.

Ho' There is no significant relationship between their age and impact of GST'

Since $\mathrm{p}$ value is not more than 0.05 the null hypothesis is rejected at $5 \%$ level of significance. Hence it is concluded that there is mean difference between impact of GST and Age of the respondents in the study area. Based on the Tukey HSD tests, the respondents who have responded with respect to satisfaction have any significant difference

Table -IV: ANOVA

Sources: Computed Data

Denotes different alpha between categories@ $5 \%$

\begin{tabular}{|c|c|c|c|c|c|c|c|}
\hline $\begin{array}{l}\text { S. } \\
\#\end{array}$ & \multicolumn{2}{|c|}{ Statement } & $\begin{array}{l}\text { Sum of } \\
\text { Squares }\end{array}$ & $\mathrm{df}$ & $\begin{array}{l}\text { Mean } \\
\text { Square }\end{array}$ & $\mathrm{F}$ & Sig. \\
\hline \multirow[t]{3}{*}{1.} & \multirow{3}{*}{$\begin{array}{l}\text { GST impacted } \\
\text { your business } \\
\text { operation }\end{array}$} & \begin{tabular}{|l|} 
Between \\
Groups
\end{tabular} & 3.784 & 3 & 1.261 & 2.594 & $\begin{array}{l}0.055 \\
*\end{array}$ \\
\hline & & \begin{tabular}{|l|} 
Within \\
Groups \\
\end{tabular} & 74.905 & 154 & 0.486 & & \\
\hline & & Total & 78.690 & 157 & & & \\
\hline \multirow[t]{3}{*}{2.} & \multirow[t]{3}{*}{\begin{tabular}{|l|} 
Sales \\
performance
\end{tabular}} & $\begin{array}{l}\text { Between } \\
\text { Groups }\end{array}$ & 12.947 & 3 & 4.316 & 6.169 & 0.001 \\
\hline & & $\begin{array}{l}\text { Within } \\
\text { Groups } \\
\end{array}$ & 107.736 & 154 & 0.700 & & \\
\hline & & \begin{tabular}{|l|} 
Total \\
\end{tabular} & 120.684 & 157 & & & \\
\hline \multirow[t]{3}{*}{3.} & \multirow[t]{3}{*}{$\begin{array}{l}\text { Service Sector } \\
\text { get costlier }\end{array}$} & $\begin{array}{l}\text { Between } \\
\text { Groups }\end{array}$ & 4.246 & 3 & 1.415 & 3.649 & 0.014 \\
\hline & & \begin{tabular}{|l|} 
Within \\
Groups \\
\end{tabular} & 59.729 & 154 & 0.388 & & \\
\hline & & Total & 63.975 & 157 & & & \\
\hline \multirow[t]{3}{*}{4.} & \multirow[t]{3}{*}{ Filing of taxes } & $\begin{array}{l}\text { Between } \\
\text { Groups }\end{array}$ & 4.246 & 3 & 1.415 & 3.649 & 0.014 \\
\hline & & $\begin{array}{l}\text { Within } \\
\text { Groups }\end{array}$ & 59.729 & 154 & 0.388 & & \\
\hline & & Total & 63.975 & 157 & & & \\
\hline \multirow[t]{3}{*}{5 . } & \multirow[t]{3}{*}{$\begin{array}{l}\text { Logistical } \\
\text { overheads }\end{array}$} & $\begin{array}{l}\text { Between } \\
\text { Groups }\end{array}$ & 3.425 & 3 & 1.142 & 2.654 & 0.051 \\
\hline & & $\begin{array}{l}\text { Within } \\
\text { Groups } \\
\end{array}$ & 66.252 & 154 & 0.430 & & \\
\hline & & Total & 69.677 & 157 & & & \\
\hline \multirow[t]{3}{*}{6.} & \multirow[t]{3}{*}{$\begin{array}{l}\text { Purchase of } \\
\text { capital goods }\end{array}$} & $\begin{array}{l}\text { Between } \\
\text { Groups }\end{array}$ & 5.260 & 3 & 1.753 & 4.328 & 0.006 \\
\hline & & $\begin{array}{l}\text { Within } \\
\text { Groups }\end{array}$ & 62.392 & 154 & 0.405 & & \\
\hline & & Total & 67.652 & 157 & & & \\
\hline \multirow[t]{3}{*}{7.} & \multirow{3}{*}{$\begin{array}{l}\text { Online } \\
\text { Compliance } \\
\text { Procedures }\end{array}$} & $\begin{array}{l}\text { Between } \\
\text { Groups }\end{array}$ & 4.443 & 3 & 1.481 & 2.943 & 0.035 \\
\hline & & $\begin{array}{l}\text { Within } \\
\text { Groups }\end{array}$ & 77.506 & 154 & 0.503 & & \\
\hline & & \begin{tabular}{|l|} 
Total \\
\end{tabular} & 81.949 & 157 & & & \\
\hline \multirow[t]{3}{*}{8.} & \multirow[t]{3}{*}{$\begin{array}{l}\text { Elimination of } \\
\text { multiple taxes }\end{array}$} & \begin{tabular}{|l} 
Between \\
Groups
\end{tabular} & 11.949 & 3 & 3.983 & 5.715 & 0.001 \\
\hline & & $\begin{array}{l}\text { Within } \\
\text { Groups }\end{array}$ & 107.323 & 154 & 0.697 & & \\
\hline & & Total & 119.272 & 157 & & & \\
\hline
\end{tabular}

significant using Tukey HSD test

*denotes Significant at $5 \%$ level

\section{BETWEEN INCOME AND IMPACT OF IMPLEMENTATION OF GST}

This section the researcher attempts to test whether the income of the respondents affects the impact of GST. For this purpose the researcher has framed the hypothesis and tested it with the help of ANOVA test and the results are presented in the below.

Ho' There is no significant relationship between their income and impact of GST' 
Table -V:ANOVA

\begin{tabular}{|c|c|c|c|c|c|c|c|}
\hline & \multicolumn{2}{|c|}{ Statement } & \multirow{2}{*}{\begin{tabular}{|r|}
$\begin{array}{l}\text { Sum of } \\
\text { Squares }\end{array}$ \\
1.267
\end{tabular}} & \multirow{2}{*}{$\begin{array}{l}\text { df } \\
3\end{array}$} & \multirow{2}{*}{$\begin{array}{l}\begin{array}{l}\text { Mean } \\
\text { Squar } \\
\text { e }\end{array} \\
0.422\end{array}$} & \multirow{2}{*}{$\begin{array}{l}\text { F } \\
0.84 \\
0 \\
\end{array}$} & \multirow{2}{*}{$\begin{array}{l}\text { Sig. } \\
0.474^{*}\end{array}$} \\
\hline 1 & \multirow{3}{*}{$\begin{array}{l}\text { GST impacted } \\
\text { your business } \\
\text { operation }\end{array}$} & $\begin{array}{l}\text { Between } \\
\text { Groups }\end{array}$ & & & & & \\
\hline & & $\begin{array}{l}\text { Within } \\
\text { Groups }\end{array}$ & 77.423 & 154 & 0.503 & & \\
\hline & & Total & 78.690 & 157 & & & \\
\hline \multirow[t]{3}{*}{2} & \multirow[t]{3}{*}{$\begin{array}{l}\text { Sales } \\
\text { performance }\end{array}$} & $\begin{array}{l}\text { Between } \\
\text { Groups }\end{array}$ & 5.432 & 3 & 1.811 & $\begin{array}{r}2.41 \\
9\end{array}$ & $0.068 *$ \\
\hline & & $\begin{array}{l}\text { Within } \\
\text { Groups }\end{array}$ & 115.252 & 154 & 0.748 & & \\
\hline & & Total & 120.684 & 157 & & & \\
\hline \multirow[t]{3}{*}{3} & \multirow[t]{3}{*}{$\begin{array}{l}\text { Sales } \\
\text { performance }\end{array}$} & $\begin{array}{l}\text { Between } \\
\text { Groups }\end{array}$ & 2.233 & 3 & 0.744 & $\begin{array}{r}1.85 \\
7 \\
\end{array}$ & $0.139 *$ \\
\hline & & $\begin{array}{l}\text { Within } \\
\text { Groups }\end{array}$ & 61.741 & 154 & 0.401 & & \\
\hline & & Total & 63.975 & 157 & & & \\
\hline \multirow[t]{3}{*}{4} & \multirow{3}{*}{$\begin{array}{l}\text { Business } \\
\text { management } \\
\text { including } \\
\text { bookkeeping } \\
\text { system }\end{array}$} & $\begin{array}{l}\text { Between } \\
\text { Groups }\end{array}$ & 2.672 & 3 & 0.891 & $\begin{array}{r}1.43 \\
3 \\
\end{array}$ & $0.235^{*}$ \\
\hline & & $\begin{array}{l}\text { Within } \\
\text { Groups }\end{array}$ & 95.714 & 154 & 0.622 & & \\
\hline & & Total & 98.386 & 157 & & & \\
\hline \multirow[t]{3}{*}{5} & \multirow{3}{*}{$\begin{array}{l}\text { Understandin } \\
\mathrm{g} \text { of the } \\
\text { financial } \\
\text { position of the } \\
\text { business }\end{array}$} & $\begin{array}{l}\text { Between } \\
\text { Groups }\end{array}$ & 38.158 & 3 & $\begin{array}{r}12.71 \\
9 \\
\end{array}$ & $\begin{array}{r}1.26 \\
7\end{array}$ & $0.288 *$ \\
\hline & & $\begin{array}{l}\text { Within } \\
\text { Groups }\end{array}$ & $\begin{array}{r}1545.95 \\
0\end{array}$ & 154 & $\begin{array}{r}10.03 \\
9\end{array}$ & & \\
\hline & & Total & $\begin{array}{r}1584.10 \\
8\end{array}$ & 157 & & & \\
\hline \multirow[t]{3}{*}{6} & \multirow[t]{3}{*}{ Filing of taxes } & $\begin{array}{l}\text { Between } \\
\text { Groups }\end{array}$ & 2.233 & 3 & 0.744 & $\begin{array}{r}1.85 \\
7\end{array}$ & $0.139 *$ \\
\hline & & $\begin{array}{l}\text { Within } \\
\text { Groups }\end{array}$ & 61.741 & 154 & 0.401 & & \\
\hline & & Total & 63.975 & 157 & & & \\
\hline \multirow[t]{3}{*}{7} & \multirow[t]{3}{*}{$\begin{array}{l}\text { Logistical } \\
\text { overheads }\end{array}$} & $\begin{array}{l}\text { Between } \\
\text { Groups }\end{array}$ & 2.728 & 3 & 0.909 & $\begin{array}{r}2.09 \\
1\end{array}$ & $0.104 *$ \\
\hline & & $\begin{array}{l}\text { Within } \\
\text { Groups }\end{array}$ & 66.950 & 154 & 0.435 & & \\
\hline & & Total & 69.677 & 157 & & & \\
\hline \multirow[t]{3}{*}{8} & \multirow[t]{3}{*}{$\begin{array}{l}\text { Elimination of } \\
\text { multiple taxes }\end{array}$} & $\begin{array}{l}\text { Between } \\
\text { Groups }\end{array}$ & 5.871 & 3 & 1.957 & $\begin{array}{r}2.65 \\
8 \\
\end{array}$ & $0.050 *$ \\
\hline & & $\begin{array}{l}\text { Within } \\
\text { Groups }\end{array}$ & 113.401 & 154 & 0.736 & & \\
\hline & & Total & 119.272 & 157 & & & \\
\hline
\end{tabular}

Source: Computed Data

Denotes different alpha between categories@ $5 \%$ significant using Tukey HSD test *denotes Significant at $5 \%$ level

Since $\mathrm{p}$ value is more than 0.05 the null hypothesis is accepted at 5\% level of significance. Hence it is concluded that there is no mean difference between impact of GST and income of the respondents in the study area. Based on the Tukey HSD test, the respondents who have responded with respect to impact of GST on the MSMEs entrepreneurs do not have any significant difference between income of the entrepreneurs.

\section{REGRESSION ANALYSIS OF DEMOGRAPHICAL FACTORS AND IMPACT OF GST ON MSMES}

The regression analysis is conducted to find out the effect of selected demographic factor on the dependent variables. The result is shown in the below table.

Table-VI: Regression

\begin{tabular}{|l|l|l|l|l|l|l|}
\hline Model & $\mathrm{R}$ & $\begin{array}{l}\mathrm{R} \\
\text { Square }\end{array}$ & $\begin{array}{l}\text { Adjusted R } \\
\text { Square }\end{array}$ & $\begin{array}{l}\text { Std. Error } \\
\text { of the } \\
\text { Estimate }\end{array}$ & $\mathrm{F}$ & P-value \\
\hline 1 & $\begin{array}{l}0.227 \\
\mathrm{a}\end{array}$ & 0.051 & 0.020 & 0.701 & $\begin{array}{l}1.64 \\
5\end{array}$ & $0.151^{* *}$ \\
\hline
\end{tabular}

Source: Complied with Primary Data

Predictors: (Constant), Monthly Income, Education Qualification, Gender, Age, Marital Status Coefficients

\begin{tabular}{||l|l|l|l|l|l|}
\hline \multirow{2}{*}{$\begin{array}{l}\text { Demographic } \\
\text { factors }\end{array}$} & \multicolumn{2}{|l|}{$\begin{array}{l}\text { Unstandardized } \\
\text { Coefficients }\end{array}$} & $\begin{array}{l}\text { Standardized } \\
\text { Coefficients }\end{array}$ & \multirow{2}{*}{$\mathrm{B}$} & Sig. \\
\cline { 2 - 5 } & $\mathrm{B}$ & $\begin{array}{l}\text { Std. } \\
\text { Error }\end{array}$ & Beta & 6.683 & .000 \\
\hline (Constant) & 2.361 & 0.353 & & .657 & $\begin{array}{l}0.51 \\
2\end{array}$ \\
\hline Gender & 0.080 & 0.122 & 0.052 & -1.35 & $\begin{array}{l}0.17 \\
9\end{array}$ \\
\hline Age & -.116 & 0.086 & -.138 & -.725 & $\begin{array}{l}0.46 \\
9\end{array}$ \\
\hline $\begin{array}{l}\text { Marital } \\
\text { Status }\end{array}$ & -.138 & 0.191 & -.076 & 0.547 & $\begin{array}{l}0.58 \\
5\end{array}$ \\
\hline $\begin{array}{l}\text { Education } \\
\text { Qualification }\end{array}$ & 0.015 & 0.027 & 0.045 & 1.554 & $\begin{array}{l}0.12 \\
2\end{array}$ \\
\hline $\begin{array}{l}\text { Monthly } \\
\text { Income }\end{array}$ & 0.104 & 0.067 & 0.124 & & \\
\hline
\end{tabular}

Source: Complied with primary Data

Dependent variable: GST impact on MSMEs

**Significant at 0.01 size

It can be inferred that the results of the regression analysis for the impact level of GST on MSMEs, where dependent variable is GST impact on MSMEs and the independent variable are selected demographic factors. From the multiple regression tables it is noted that the value of coefficient of regression $\left(\mathrm{R}^{2}\right)$ is 0.051 which implies that $5.1 \%$ of the variance on impact of GST is explained by the independent variables used in this study. The $f$ value obtained is $1.645(\mathrm{P}<0.001)$ and hence it is concluded that there is significant relationship between dependent variable 'GST impact on MSMEs' and independent variables 'Demographic factors'

\section{FINDINGS OF THE STUDY}

1. The reliability analysis shows that all items in the scale for measuring level of impact of GST on MSMEs is acceptable for all the nineteen scale items that is indicating an excellent reliability among the nineteen scale items. 
2. The majority of the respondents are in the age group of above 51 years, followed by the respondent group with age level of 41-50 years and 31 - 40 years show that well experienced entrepreneurs are represented in the study.

3. The respondents who are Illiterate constitute majority of the total sample followed by Engineering .The monthly income level from Rs.50000 to Rs 100000 is $60.8 \%$ followed by Rs 100001 to Rs 200000 is 23.4 $\%$ of the respondents in the sample shows that most of the respondents are Micro Units followed by Small enterprises.

4. It is found from on the ANOVA test that the respondents who have responded with respect to impact of GST on the MSMEs entrepreneurs do not have any significant difference between Genders.

5. It is found from on the Tukey HSD test, the respondents who have responded with respect to impact of GST on the MSMEs have significant difference between ages of the entrepreneurs.

6. It is inferred from on the ANOVA test that, the respondents who have responded with respect to impact of GST on the MSMEs entrepreneurs do not have any significant difference between incomes of the entrepreneurs.

7. It is found from the regression analysis for the impact level of GST on MSMEs, where dependent variable is GST impact on MSMEs and the independent variables are selected demographic factors. From the multiple regressions it is concluded that there is significant relationship between dependent variable 'GST impact on MSMEs' and independent variables 'Demographic factors'.

\section{LIMITATIONS OF THE STUDY}

The present study is limited to MSME Entrepreneur in Sivaganga District. So, the findings of the study cannot be generalized for the entire population of MSME Entrepreneur in other parts of State of Tamil Nadu.

\section{CONCLUSION}

The study reflects that few of the preparedness in respect of GST by MSME entrepreneurs, need for improvising the GST network and other such related trends are turning out to be the bottle neck factors towards realizing the actual outcome of GST implementation. In lines with the impact survey conducted with small and micro enterprises, it is evident that the people rate the impact of GST as a balance and there is potential scope for improvement in the process. However, to ensure smooth and successful outcome ensuring that the implementation system is managed addressing the gaps in the process is very important. If such measures are taken up by the government in a rapid pace, it can be very resourceful outcome for sustainable economic development.

\section{REFERENCES}

1. G.Venkateswarlu, M. J. (2018). Impact of GST on Micro, Small and Medium Enterprises (MSMEs). International Journal of Engineering and Management Research, 8(2), 91-95.

2. Shetty Deepa Thangam Geeta, Mathiraj.SP \& Saroja Devi (2019) "Students Responsiveness on the Implementation of GST In Commerce Stream", in Journal of Emerging Technologies and Innovative Research (JETIR) UGC Approved Journal Vol.6, Issue 2, ISSN-2349-5162, pp-537-540, January 2019.

3. Shetty Deepa Thangam Geeta, Mathiraj.SP, Saroja Devi, N. Nagalakshmi \& M. Vinoth (2019) "Performance \& Consequences of GST on Micro, Small \& Medium Entrepreneurs", in International Journal of Research and Analytical Reviews (IJRAR) UGC Approved Journal no- 43602 Vol.6, Issue 1, ISSN-2348-1269, pp-26-37, February 2019

4. Singh, A. N. (2018, February). A Comprehensive Analysis of Goods and Services Tax (GST) in India. Indian Journal of Finance, 12(2). doi: 10.17010/ijf/2018/v12i2/121377.

5. Statistical Hand Book of Sivagangai ,2017 https://cdn.s3waas.gov.in/s31a5b1e4daae265b790965a275b53ae50 /uploads/2018/06/2018062188.pdf

6. Singh, S. S. (2018, November). GST in India : Performance of Companies After One - Year of Roll Out. INdian Journal of Finance, 12(11). doi:http://dx.doi.org/10.17010/ijf\%2F2018\%2Fv12i11\%2F138197

7. G.Venkateswarlu, M. J. (2018). Impact of GST on Micro, Small and Medium Enterprises (MSMEs). International Journal of Engineering and Management Research, 8(2), 91-95.

8. http://conference.nrjp.co.in/index.php/GST/article/download/228/231/

9. .https://cdn.s3waas.gov.in/s31a5b1e4daae265b790965a275b53ae50/u ploads/2018/06/2018062188.pdf

10. http://conference.nrjp.co.in/index.php/GST/article/download/241/2 $43 /$

11. https://acadpubl.eu/hub/2018-119-17/2/194.pdf

12. Vhttp://www.indianjournaloffinance.co.in/index.php/IJF/article/vie w/121377

13. http://dx.doi.org/10.17010/ijf\%252F2018\%252Fv12i11\%252F138 197

14. http://www.pibm.in/pdf/PIBM\%20-\%20A\%20Journal\%20of\%20M anagement $\% 20-\% 20$ Volume\%203.pdf

15. http://gstinindia.in/Impact_of_GST_on_MSME.aspx

16. http://indianresearchjournals.com/pdf/IJMFSMR/2018/August/1.pd $\mathrm{f}$

17. http://www.iosrjournals.org/iosr-jbm/papers/Vol20-issue7/Version1/J2007018183.pdf

18. http://www.smecorp.gov.my/images/pdf/1Q_2016_SMEs_Survey_ English_WEB.pdf

19. http://iosrjournals.org/iosr-jbm/papers/Vol20-issue7/Version-1/J20 07018183.pdf

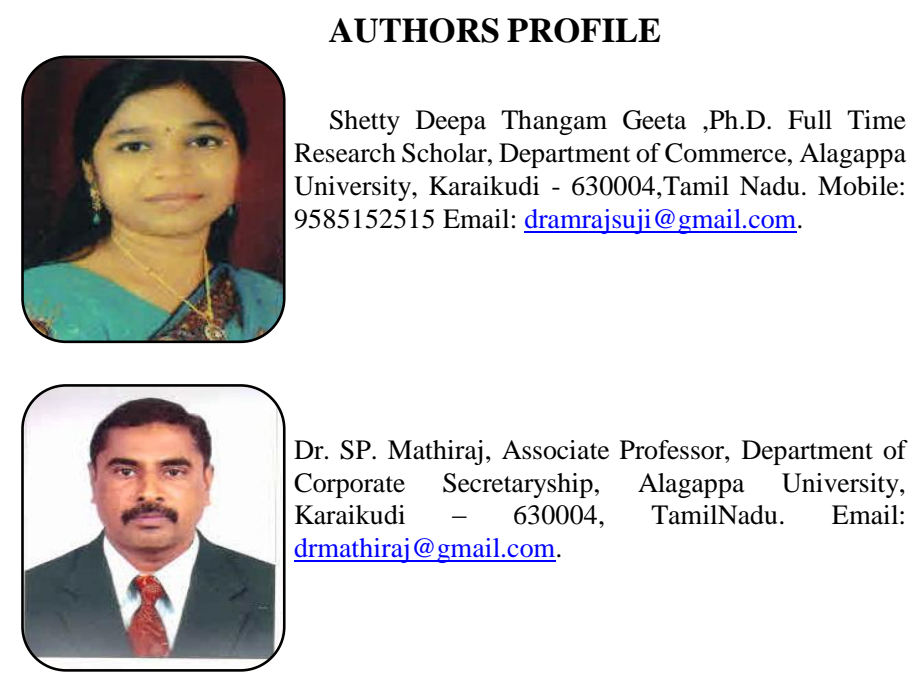




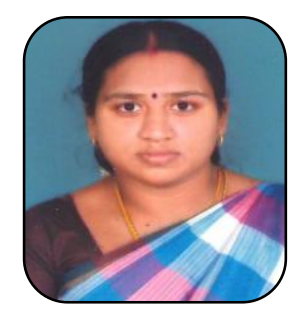

M.Thivya Bharathi ,Ph.D. Full Time Research Scholar, Department of Corporate Secretaryship,

Alagappa University, Karaikudi - 630004, Tamil

Nadu.Email: assthivya@gmail.com. 